\section{Impact of 35\% Hydrogen Peroxide on Color and Translucency Changes in Enamel and Dentin}

Rebeca Pereira de Menezes ${ }^{1}$, Paula Damasceno Silva ${ }^{2}$, Pollyana Caldeira Leal $^{3}$, André Luis Faria-e-Silva ${ }^{1}$

\author{
'Department of Dentistry, \\ UFS - University Federal de \\ Sergipe, Aracaju, SE, Brazil \\ ${ }^{2}$ Graduate Program in Dentistry, \\ UFS - University Federal de \\ Sergipe, Aracaju, SE, Brazil \\ ${ }^{3}$ Graduate Program in Physiological \\ Sciences, UFS - University Federal \\ de Sergipe, Aracaju, SE, Brazil
}

Correspondence: André Luis Faria e Silva, Rua Cláudio Batista, s/n - Sanatório, 49060-100 Aracaju, SE, Brazil. Tel: +55-79-2105-1821.

\begin{abstract}
This study evaluated the effects of tooth bleaching with high-concentration of hydrogen peroxide on alterations of translucency parameter (TP) and color of dentin and enamel. The crown of five human molars was sectioned into four slices parallel to buccal surface. The dentin of external slices containing buccal/ lingual enamel was fully removed with diamond bur; while these slices were used to assess alterations on enamel. Alterations on dentin were assessed into the center of internal slices. The color of specimens was measured over white and black backgrounds using a spectrophotometer (CieL*a*b) at baseline, allowing to calculate the TP by difference between the color measured over each background. Specimens were submitted to three 15-min applications of 35\% hydrogen peroxide followed by their storage in water for one-week. Afterwards, the color measurements were repeated at both backgrounds. Color $(\Delta \mathrm{L}, \Delta \mathrm{a}, \Delta \mathrm{b}$ and $\Delta \mathrm{E})$ and translucency $(\Delta \mathrm{TP})$ changes were calculated and data individually analyzed by T-test $(\alpha=0.05)$. Influence of hard tissue and assessment time on each color parameter was also analyzed by 2 -way repeated measure ANOVA $(\alpha=0.05)$. Tooth bleaching resulted in increased lightness for the enamel, whereas no alteration on this parameter occurred for dentin. No difference between the tooth hard tissues was observed regards the other color parameters and $\Delta \mathrm{E}$. A slightly reduction on TP was observed only for the enamel. In conclusion, 35\% hydrogen peroxide caused similar color and translucency changes on dentin and enamel.
\end{abstract} \begin{abstract}
e-mail: fariaesilva.andre@gmail.com
\end{abstract}
\section{Introduction}

The color of tooth structures results from the interaction among different phenomena of light through hard tissues including dispersion, refraction, transmission and absorption. ${ }^{1}$ Therefore, the ultimate color observed is determined by combination among optical properties of enamel and dentin tissue, including translucency and chromaticity. ${ }^{1,2}$ Due to high mineral content, the enamel is the more translucent structure of tooth allowing that the color of underlying dentin significantly affects the ultimate tooth color. ${ }^{2}$ However, changes on enamel translucency or chromaticity modifies the perception of underlying dentin and also affected the tooth color. ${ }^{3}$ The increase on chromaticity of teeth from elderly patients due the presence of more translucent enamel following the reduction on its thickness by physiological wear is a case in point. ${ }^{1}$ Thus, the knowledge about the optical properties of tooth tissues is essential to achieve excellence on esthetic procedures in dentistry, including tooth bleaching procedures.

In clinical cases of tooth discoloration, the tooth bleaching procedures using hydrogen peroxides are usually performed seeking out to increase the lightness and to reduce the yellowness/ redness of teeth. ${ }^{4,5}$ Tooth bleaching procedures are performed either in-office or at-home using high- and low-concentration peroxides (hydrogen or carbamide peroxide). ${ }^{6}$ Regardless the protocol or bleaching used, the peroxides and their sub-products oxide the organic structure of tooth substrates resulting in lighter aspect. ${ }^{7.8}$ Considering the higher organic content and chromaticity of dentin, it is reasonable to relate the bleaching effect mainly to optical modifications on this tissue. However, the role of each hard tooth tissue on bleaching effect remains controversial. ${ }^{9-13}$ Some studies reported that the enamel played a more important role than dentin in tooth bleaching. ${ }^{11,12} \mathrm{On}$ the other hand, bleaching of dentin has been associated to tooth color changes instead modifications on enamel. 9,10

Thus, the aim of this study was to assess the color and translucency changes caused by tooth bleaching on dentinal and enamel tissues. The null hypothesis was that the tooth bleaching using high-concentration hydrogen peroxide results in similar color and translucency changes on enamel and dentin.

\section{Material and Methods}

Five sound human third molars (without any crack, caries lesion, restoration, or severe wear) were sectioned 
parallel to buccal/lingual faces to obtain four slices using a diamond disc in a cutting machine (Isomet low speed, Buehler, Lake Forest, IL, USA). The dentin of two more external slices containing the buccal/ lingual enamel were removed using a diamond bur, maintaining only the enamel tissue. These slices were used to assess the optical modifications on enamel. The other internal slices presenting dentin covered by occlusal enamel was used to measure color and translucency changes in dentin. For this purpose, the readings were carried out only in the center of these last slices. Impressions of the specimens were taken with dense polydimethylsiloxane impression material (Perfil, Coltene-Whaledent, Altstätten, Switzerland) to standardize the local of measurements during the entire experiment. A perforation with $6 \mathrm{~mm}$ of diameter was created in the mold to allow the placement of the spectrophotometer tip (Easy Shade Compact, Vita-Zahnfabrik, Bad Säckinge, Germany).

The color (CieL*a*b) of all specimens at baseline was measured over white and black backgrounds to allow the translucency parameter (TP) calculation using the followed formula ${ }^{14}: T P=\left(\left(L_{\text {white }}-L_{\text {black }}\right)^{2}+\left(a_{\text {white }}-\right.\right.$ $\left.\left.a_{\text {black }}\right)^{2}+\left(b_{\text {white }}-b_{\text {black }}\right)^{2}\right)^{1 / 2}$. Afterwards, the specimens were submitted to tooth bleaching with 35\% hydrogen peroxide (Whiteness HP Maxx, FGM, Joinvile, SC, Brazil) with three consecutive applications of 15 minutes each. After bleaching procedures, the specimens were stored in water for 7 days prior to measurement of bleaching effect. The color was measured again under both backgrounds and TP of specimens calculated again. The color changes were calculated for each parameter $(\Delta \mathrm{L}, \Delta \mathrm{a}$ and $\Delta \mathrm{b})$ using only the data from white background. The pooled color change $(\Delta \mathrm{E})$ was calculated using the followed formula: $\Delta \mathrm{E}$ $=\left(\left(\mathrm{L}_{\text {baseline }}-\mathrm{L}_{\text {final }}\right)^{2}+\left(\mathrm{a}_{\text {baseline }}-\mathrm{a}_{\text {final }}\right)^{2}+\left(\mathrm{b}_{\text {baseline }}-\mathrm{b}_{\text {final }}\right)^{2}\right)^{1 / 2}$. Changes on translucency $(\Delta T P)$ caused by the bleaching procedure was calculated subtracting the final values from those observed on baseline. Data of $\Delta \mathrm{L}, \Delta \mathrm{a}, \Delta \mathrm{b}, \Delta \mathrm{E}$ and $\Delta \mathrm{TP}$ were individually analyzed by T-test comparing the hard tissues for each color parameter $(\alpha=0.05)$. Normal distribution of data was assessed by Shapiro-Wilk test and data of color parameters $(\mathrm{L}, \mathrm{a}$ and $\mathrm{b})$ were individually submitted to Two Way Repeated Measures ANOVA, while "assessment time" was defined as repetition factor. All analyses were performed using the SigmaStat v.3.5 statistical software package (Systat Software Inc., Chicago, IL, USA).

\section{Results}

Table 1 presents the results for color and translucency changes observed in both hard tissues. Tooth bleaching increased the lightness $(\Delta \mathrm{L})$ measured on enamel and did not affected this color parameter on dentin. Irrespective the tooth tissue evaluated, no modification on red-green axis $(\Delta \mathrm{a})$ was observed. Dentin and enamel became less yellow (reduction on $\Delta \mathrm{b}$ ) after the tooth bleaching without significant difference between these tissues. No difference between the tooth hard tissues was also observed for pooled color change $(\Delta \mathrm{E})$. The enamel become slightly less translucent after the tooth bleaching procedure, and the translucency change observed for this tissue differed from that measured in the dentin.

Table 2 shows the color measured at baseline and after the tooth bleaching. Two Way Repeated Measures ANOVA showed that both "hard tissue" $(p=0.002)$ and "assessment time" ( $p=0.002)$ significantly affected the "L" values, but there was a significant interaction between these factors $(p=0.001)$. At both assessment times, enamel showed higher "L" value than dentin. The tooth bleaching significantly increased the "L" value for enamel, and did not modify the values for dentin. Regarding the parameter "a", neither factors ("hard tissue" - $p=0.062$; "assessment time" $p=0.721)$ or interaction $(p=0.165)$ significantly affected this

Table 1. Means (95\% confidence interval) of color and translucency changes caused by tooth bleaching with 35\% hydrogen peroxide on dentin and enamel hard tissues $(n=10)$

\begin{tabular}{|c|c|c|c|}
\hline \multirow{2}{*}{ Outcomes } & \multicolumn{2}{|c|}{ Hard tissue } & \multirow{2}{*}{$p$ value* } \\
\hline & Dentin & Enamel & \\
\hline$\Delta \mathrm{L}$ & $-0.2(-2.7$ to 2.4$)$ & 5.7 (4.2 to 7.2$)$ & 0.001 \\
\hline$\Delta \mathrm{a}$ & $0.4(-0.8$ to 1.7$)$ & $-0.7(-1.6$ to 0.2$)$ & 0.165 \\
\hline$\Delta \mathrm{b}$ & $-8.4(-10.0$ to -6.8$)$ & $-7.6(-9.8$ to 5.5$)$ & 0.575 \\
\hline$\Delta \mathrm{E}$ & 9.6 (8.4 to 10.8 ) & $9.9(7.7$ to 12.1$)$ & 0.832 \\
\hline$\Delta \mathrm{TP}$ & $0.3(-0.4$ to 1.1$)$ & $-0.9(-1.7$ to -0.1$)$ & 0.044 \\
\hline
\end{tabular}

* T-test.

Table 2. Means (95\% confidence interval) of each color parameter measured at baseline and after the tooth bleaching on dentin and enamel hard tissues $(\mathrm{n}=10)$.

\begin{tabular}{lccc}
\hline \multirow{2}{*}{$\begin{array}{l}\text { Color } \\
\text { parameter }\end{array}$} & Assessment & \multicolumn{2}{c}{ Hard tissue } \\
\cline { 3 - 4 } & time & Dentin & Enamel \\
\hline \multirow{2}{*}{$\mathrm{L}$} & Baseline & $69.9(65.5 \text { to } 74.4)^{\mathrm{Ab}}$ & $76.5(73.9 \text { to } 79.2)^{\mathrm{Ba}}$ \\
& Final & $69.8(65.1 \text { to } 74.4)^{\mathrm{Ab}}$ & $82.2(79.7 \text { to } 84.7)^{\mathrm{Aa}}$ \\
$\mathrm{a}$ & Baseline & $-1.7(-2.8 \text { to }-0.6)^{\mathrm{Aa}}$ & $-2.4(-3.4 \text { to }-1.5)^{\mathrm{Aa}}$ \\
& Final & $-1.3(-2.7 \text { to } 0.2)^{\mathrm{Aa}}$ & $-3.1(-3.6 \text { to }-2.7)^{\mathrm{Aa}}$ \\
$\mathrm{b}$ & Baseline & $30.5(25.3 \text { to } 35.7)^{\mathrm{Aa}}$ & $32.0(28.5 \text { to } 35.5)^{\mathrm{Aa}}$ \\
& Final & $22.2(17.4 \text { to } 26.7)^{\mathrm{Ba}}$ & $24.4(21.4 \text { to } 27.3)^{\mathrm{Ba}}$ \\
\hline
\end{tabular}

For each color parameter, distinct letters (uppercase for column comparing assessment times; lowercase for line comparing hard tissues) indicate statistically significant difference $(\mathrm{p}<0.05)$. 
outcome. For the parameter " $b$ ", only the "assessment time" $(p<0.001)$ affected the results, while "hard tissue" $(p=0.517)$ and the interaction were not significant $(p=0.575)$. Figure 1 presents the changes on parameters $L$, a and $b$ caused by tooth bleaching with 35\% hydrogen peroxide.

\section{Discussion}

In the present study, the bleaching effectiveness on tooth tissues was evaluated using enamel and dentin tissues separately, whereas these tissues are bonded under clinical conditions. This approach was performed in the present study once that the methodology used does not allow to evaluate the bleaching effect on each tissue using specimens containing both dentin and enamel. The outcomes demonstrated changes on translucency only for the enamel. Regarding the tooth color, despite similar pooled color changes caused by hydrogen peroxide for both tissues, the lightness of color was increased only for the enamel, with significant difference for the $\Delta \mathrm{L}$ achieved in the dentin. Thus, null hypothesis of the study was rejected.

The bleaching agent used in the present study is recommended for be applied over the enamel during inoffice tooth bleaching procedures. In opposite, bleaching agents are applied directly over the dentinal tissue only when internal bleaching procedures are performed in non-vital teeth, while the agent is placed into the pulpal chamber. ${ }^{15-18}$ Usually, internal tooth bleaching procedures

are carried out with sodium perborate or carbamide peroxide based bleaching agents in a so-called walking bleaching (mediate technique). 15,17,18 However, high-concentration hydrogen peroxide is also used for immediate internal tooth bleaching. ${ }^{19-21}$ This last approach was simulated in the present study seeking out to evaluate the effects of the same bleaching agent over the different tooth hard tissues. It is important to emphasize that the findings of present study for dentin can't be extrapolated to external bleaching procedures. During the external tooth bleaching procedures, the bleaching agent is applied over the enamel and reach the underlay dentin after to diffuse through the former tissue. Thus, it is expected that a lower concentration of peroxide will reach the dentin than that applied over the enamel. ${ }^{22}$ Considering that the bleaching effect is related to peroxide concentration, ${ }^{23,24}$ it is reasonable to believe that a reduced color alteration could be observed for the dentin in this situation than that found the present study.

It has been reported that the bleaching effect of tooth tissue is related to oxidation of organic components. ${ }^{8}$ Thus, it could be expected higher bleaching effect on dentin, which present higher organic content than enamel. However, other studies have reported that the enamel contributes more than dentin to tooth bleaching effect observed..$^{11,12}$ In fact, the results of the present study found increased lightness (more white) and slight reduction on translucency (increased opacity) of enamel after hydrogen peroxide application; whereas no change on dentin was observed for these parameters. Once that the enamel acts as filter to dentin color, the presence of more opaque enamel reduced the yellowness of dentin resulting in bleaching effect. When other color parameters were evaluated, no
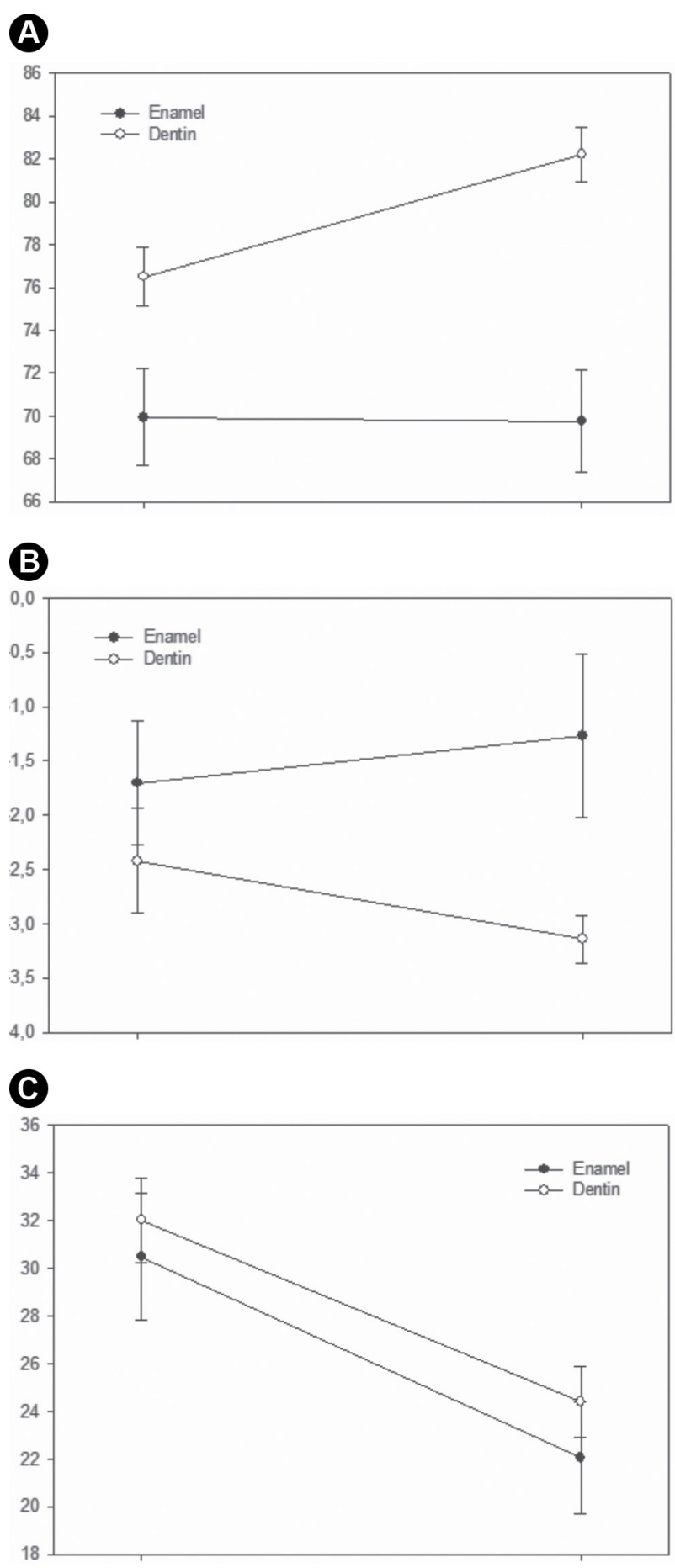

Figure 1. Changes on color parameters caused by application of 35\% hydrogen peroxide. (A) L, (B) a, and (C) b. 
modification on red-green axis $(\Delta \mathrm{a})$ was observed for both tissues, whereas the tooth bleaching procedure cause significant reduction on yellowness (reduction on $\Delta b$ ) without difference between dentin and enamel. Therefore, the color change $(\Delta \mathrm{E})$ observed in dentin was strongly affected by yellowness reduction, while both lightness increasing and yellowness reduction affected the ultimate color of bleached enamel. Similar findings were observed when each color parameter was assessed at baseline and after tooth bleaching, and differences between the hard tissues were found only for lightness.

Further to color changes, alteration on translucency parameter caused by tooth bleaching also was evaluated in the present study. Translucency is defined as the ability of structures to allow the light-transmission through of it and strongly depends on reflectance of internal pigments from substrate, while thick structures results in reduced light-transmission. ${ }^{2,3}$ In the present study, TP was assessed by difference between color parameters recorded over black and white backgrounds. The rationale is that changing the background color does not affect the measurements for an opaque object, whereas significant difference on color is expected for more translucent objects. One limitation of the methodology used in the present study was the impossibility to standardization of specimens' thickness. Considering that the thickness significantly affects the translucency, we chosen to use the changes on the TP observed in each specimen in the data analyses. ${ }^{25,26}$

Changes on TP were observed only for the enamel, which became more opaque. The explanation for differences on TP changes between the hard tooth tissues evaluated is related to mineral content. Enamel is made up of more inorganic components by volume (higher than 97\%) than dentin (approximately 50\%). ${ }^{27}$ The use of hydrogen peroxides over the tooth substrates reduces the mineral content due to demineralization of enamel prism and possible non-prismatic layer removal. ${ }^{28}$ The modification on enamel surface that became more rough rises the light-diffusion and consequently decrease the light-transmission. ${ }^{29}$ On the other hand, no significant modification could be expected to the dentin tissue due to its lower mineral content when compared to enamel. Possible modifications on surface roughness also help to explain the occurrence of lightness changes only for enamel. Rougher surface tends to reflect more light and ultimately increase the lightness of structure.

In conclusion, the outcomes of the present study demonstrated that 35\% hydrogen peroxide results in similar pooled color changes in enamel and dentinal tissues, despite increase on lightness was observed only for the enamel. Moreover, translucency change was observed only for the enamel that became slightly more opaque.

\section{Resumo}

Este estudo avaliou os efeitos do clareamento dental com peróxido de hidrogênio em alta concentração nas alterações do parâmetro de translucidez (PT) e cor da dentina e esmalte. A coroa de cinco molares humanos foi seccionada em quatro fatias paralelas à superficie vestibular. A dentina das fatias externas contendo esmalte vestibular/ lingual foi totalmente removida com ponta diamantada, sendo estas fatias usadas para verificar as alterações no esmalte. Alterações na dentina foram verificadas no centro das fatias internas. A cor das amostras foi mensurada sobre fundos preto e branco usando um espectrofotômetro (CieL*a*b) no início, permitindo calcular o PT pela diferença de cor medida sobre cada fundo. As amostras foram submetidas a três aplicações de 15 minutos de peróxido de hidrogênio a 35\% seguido pelo seu armazenamento em água por uma semana. Após isto, as mensurações de cor foram repetidas em ambos os fundos. Mudanças de $\operatorname{cor}(\Delta \mathrm{L}, \Delta \mathrm{a}, \Delta \mathrm{b}$ e $\Delta \mathrm{E})$ e translucidez $(\Delta \mathrm{PT})$ foram calculadas e os dados analisados pelo Teste $\mathrm{T}(\alpha=0,05)$. A influência do tecido duro e do momento de avaliação em cada parâmetro de cor foi também analisado através de ANOVA de duas vias para medidas repetidas $(\alpha=0,05)$. 0 clareamento dental resultou em maior luminosidade $(\Delta \mathrm{L})$ para o esmalte, enquanto que nenhuma alteração neste parâmetro ocorreu para a dentina. Nenhuma diferença entre os tecidos duros dentais foi observada em relação aos outros parâmetros de cor e $\Delta \mathrm{E}$. Uma leve redução na PT foi observada apenas para o esmalte. Como conclusão, peróxido de hidrogênio a $35 \%$ causou similar alteração de cor e translucidez no esmalte e na dentina.

\section{References}

1. Villarroel M, Fahl N, De Sousa AM, De Oliveira OB Jr. Direct esthetic restorations based on translucency and opacity of composite resins. J Esthet Restor Dent 2011;23:73-87.

2. Hasegawa $A$, Ikeda I, Kawaguchi S. Color and translucency of in vivo natural central incisors. J Prosthet Dent 2000;83:418-423.

3. Lee YK. Translucency of human teeth and dental restorative materials and its clinical relevance. J Biomed Opt 2015;20:045002.

4. Matis BA, Cochran MA, Eckert G. Review of the effectiveness of various tooth whitening systems. Oper Dent 2009;34:230-235.

5. Rezende $M$, Loguercio $A D$, Kossatz $S$, Reis A. Predictive factors on the efficacy and risk/intensity of tooth sensitivity of dental bleaching: $A$ multi regression and logistic analysis. J Dent 2016;45:1-6.

6. de Geus JL, Wambier LM, Kossatz S, Loguercio AD, Reis A. At-home vs In-office Bleaching: A Systematic Review and Meta-analysis. Oper Dent 2016;41:341-356.

7. Kwon SR, Wertz PW. Review of the Mechanism of Tooth Whitening. J Esthet Rest Dent 2015;27:240-257.

8. Eimar $H$, Siciliano $R$, Abdallah MN, Nader SA, Amin WM, Martinez PP, Celemin A, Cerruti M, Tamimi F. Hydrogen peroxide whitens teeth by oxidizing the organic structure. J Dent 2012;40:e25-e33.

9. McCaslin AJ, Haywood VB, Potter BJ, Dickinson GL, Russell CM. Assessing dentin color changes from nightguard vital bleaching. J Am Dent Assoc 1999;130:1485-1490.

10. Wiegand A, Vollmer D, Foitzik M, Attin R, Attin T. Efficacy of different whitening modalities on bovine enamel and dentin. Clin Oral Investig 2005;9:91-97.

11. Kugel G, Petkevis J, Gurgan S, Doherty E. Separate whitening effects on enamel and dentin after fourteen days. J Endod 2007;33:34-37.

12. $M a X, L i R, S a Y$, Liang $S$, Sun $L$, Jiang $T$, Wang $Y$. Separate contribution of enamel and dentine to overall tooth colour change in tooth bleaching. J Dent 2011;39:739-745.

13. Caneppele TM, Borges AB, Torres CR. Effects of dental bleaching on the color, translucency and fluorescence properties of enamel and dentin. Eur J Esthet Dent 2013;8:200-212.

14. Boscato N, Hauschild FG, Kaizer MR, De Moraes RR. Effectiveness of Combination of Dentin and Enamel Layers on the Masking Ability of Porcelain. Braz Dent J 2015;26:654-659.

15. Plotino G, Buono L, Grande NM, Pameijer CH, Somma F. Nonvital tooth bleaching: a review of the literature and clinical procedures. J Endod 
2008;34:394-407.

16. Abbott P, Heah SY. Internal bleaching of teeth: an analysis of 255 teeth. Aust Dent J 2009;54:326-33.

17. Palo RM, Valera MC, Camargo SE, Camargo $\mathrm{CH}$, Cardoso $\mathrm{PE}$, Mancini $\mathrm{MN}$, Pameijer $\mathrm{CH}$. Peroxide penetration from the pulp chamber to the external root surface after internal bleaching. Am J Dent 2010;23:171174.

18. Kirchhoff AL, Raldi DP, Salles AC, Cunha RS, Mello I. Tooth discolouration and internal bleaching after the use of triple antibiotic paste. Int Endod J 2015;48:1181-1187.

19. Rodrigues LM, Vansan LP, Pécora JD, Marchesan MA. Permeability of different groups of maxillary teeth after 38\% hydrogen peroxide internal bleaching. Braz Dent J 2009;20:303-306.

20. Azevedo RA, Silva-Sousa YT, Souza-Gabriel AE, Messias DC, Alfredo E, Silva RG. Fracture resistance of teeth subjected to internal bleaching and restored with different procedures. Braz Dent J 2011;22:117-121.

21. Palo RM, Bonetti-Filho I, Valera MC, Camargo $\mathrm{CH}$, Camargo $\mathrm{S}$, MouraNetto C, Pameijer C. Quantification of peroxide ion passage in dentin, enamel, and cementum after internal bleaching with hydrogen peroxide. Oper Dent 2012;37:660-664.

22. de Almeida LC, Soares DG, Gallinari MO, de Souza Costa CA, Dos Santos $\mathrm{PH}$, Briso AL. Color alteration, hydrogen peroxide diffusion, and cytotoxicity caused by in-office bleaching protocols. Clin Oral Investig 2015;19:673-680.

23. Borges AB, Zanatta RF, Barros AC, Silva LC, Pucci CR, Torres CR. Effect of hydrogen peroxide concentration on enamel color and microhardness. Oper Dent 2015;40:96-101.
24. Mena-Serrano AP, Garcia E, Luque-Martinez I, Grande R, Loguercio AD, Reis A. A Single-Blind Randomized Trial About the Effect of Hydrogen Peroxide Concentration on Light-Activated Bleaching. Oper Dent 2016;41:455-464.

25. Shiraishi T, Watanabe I. Thickness dependence of light transmittance, translucency and opalescence of a ceria-stabilized zirconia/alumina nanocomposite for dental applications. Dent Mater 2016;32:660-667.

26. Kim EH, Jung KH, Son SA, Hur B, Kwon YH, Park JK. Effect of resin thickness on the microhardness and optical properties of bulk-fill resin composites. Restor Dent Endod 2015;40:128-135.

27. Chien YC, Burwell AK, Saeki K, Fernandez-Martinez A, Pugach MK, Nonomura G, Habelitz S, Ho SP, Rapozo-Hilo M, Featherstone JD, Marshall SJ, Marshall GW. Distinct decalcification process of dentin by different cariogenic organic acids: Kinetics, ultrastructure and mechanical properties. Arch Oral Biol 2016;63:93-105.

28. Bitter NC. A scanning electron microscope study of the long-term effect of bleaching agents on the enamel surface in vivo. Gen Dent 1998;46:84-88.

29. Akar GC, Pekkan G, Çal E, Eskitaşçığlu G, Özcan M. Effects of surfacefinishing protocols on the roughness, color change, and translucency of different ceramic systems. J Prosthet Dent 2014;112:314-21.

Received February 22, 2017 Accepted July 11, 2017 